\title{
Heavy metals in the waters of Dąbie Lake (West-Pomeranian Voievodship, North-West Poland)
}

\author{
Piotr Daniszewski \\ Department of Invertebrate Zoology and Limnology, Faculty of Biology \\ University of Szczecin, 13 Wąska Street, 71-415 Szczecin, Poland \\ E-mail address: daniszewski73@gmail.com
}

\begin{abstract}
Heavy metal pollution is an ever increasing problem of our lakes. These toxic heavy metals entering in aquatic environment are adsorbed onto particulate matter, although they can form free metal ions and soluble complexes that are available for uptake by biological organisms. The increase in residue levels of heavy metal content in water, sediments and biota has resulted in decreased productivity and increase in exposure of humans to harmful substances. Many of these metals tend to remain in the ecosystem and eventually move from one compartment to the other within the food chain. Food chain contamination by heavy metals has become a burning issue in recent years because of their potential accumulation in biosystems through contaminated water, soil, sediment and air.

Dąbie Lake is an integral part of the River Odra estuary. It is a shallow ( $2.5 \mathrm{~m}$ mean depth) water body with two distinct basins: the large (Dąbie Wielkie) and the small (Dąbie Małe). The aim of the studies, carried out in the years 2008 - 2009, was to determine the content of Cadmium (Cd), Chromium (Cr), Copper $(\mathrm{Cu})$, Mercury $(\mathrm{Hg})$, Nickel $(\mathrm{Ni})$, Lead $(\mathrm{Pb})$ and Zinc $(\mathrm{Zn})$ in the waters of Dąbie Lake, being the internal part of the tertiary Odra estuary.
\end{abstract}

Keywords: Heavy metal pollution; metals in water; Dąbie Lake (North-West Poland); pollution; environment

\section{INTRODUCTION}

The term "heavy metals" refers to any metallic element that has a relatively high density and applies to the group of metals and metalloids with atomic density greater than $4 \mathrm{~g} \cdot \mathrm{cm}^{-3}$. Heavy metals are well known to be toxic to most organisms when present in high concentration in the environment [4-6,8,9,16,23,29]. In the last decades, human activities have continuously increased the levels of heavy metals circulating in the environment. Anthropogenic activities such as agriculture, industry and urban life increase content of these elements in soils and waters $[1,2,5,7,9,11,14,15,19,20,24]$.

Many of these metals tend to remain in the ecosystem and eventually move from one compartment to the other within the food chain [19,20,36-46,51-60]. Food chain contamination by heavy metals has become a burning issue in recent years because of their potential accumulation in biosystems through contaminated water, soil, sediment and air [19,20,56-60].

Heavy metals, diluted in water, are usually in ionic or colloidal form. They are partly taken in by water organisms into their cells and tissues and partly absorbed by inorganic particles in suspension [36-46,51-60,73-75]. Organic matter, released into water after the 
decay of bacteria, plants and animals containing a certain amount of heavy metals absorbed earlier can additionally absorb more metals from the water [9-17,20,22-35,36-46,51-60,7375]. With time organic and inorganic suspension falls down forming bottom sediments [917,20,22-35,36-46,51-60,73-75].

Hence in the present investigation, efforts are made to quantify the accumulation of toxic heavy metals in water of Dąbie Lake of North-West Poland. The study was carried out with an objective to generate the pollution load data from scientific study so as to gauge the extent of pollution due to toxic heavy metals in the lake water.

\section{EXPERIMENTAL}

Dąbie Lake is an integral part of the River Odra estuary. It is a shallow (2.5 m mean depth) water body with two distinct basins: the large (Dąbie Wielkie) and the small (Dąbie Małe) [72,76-78].

The nature of Lake Dąbie, its location and hydrodynamics render the lake particularly important for the regional economy. The lake supports about 40 fish species; the major constituent of commercial fisheries involves benthophagous fish which account for $75-80 \%$ of all landings [72,76-78].

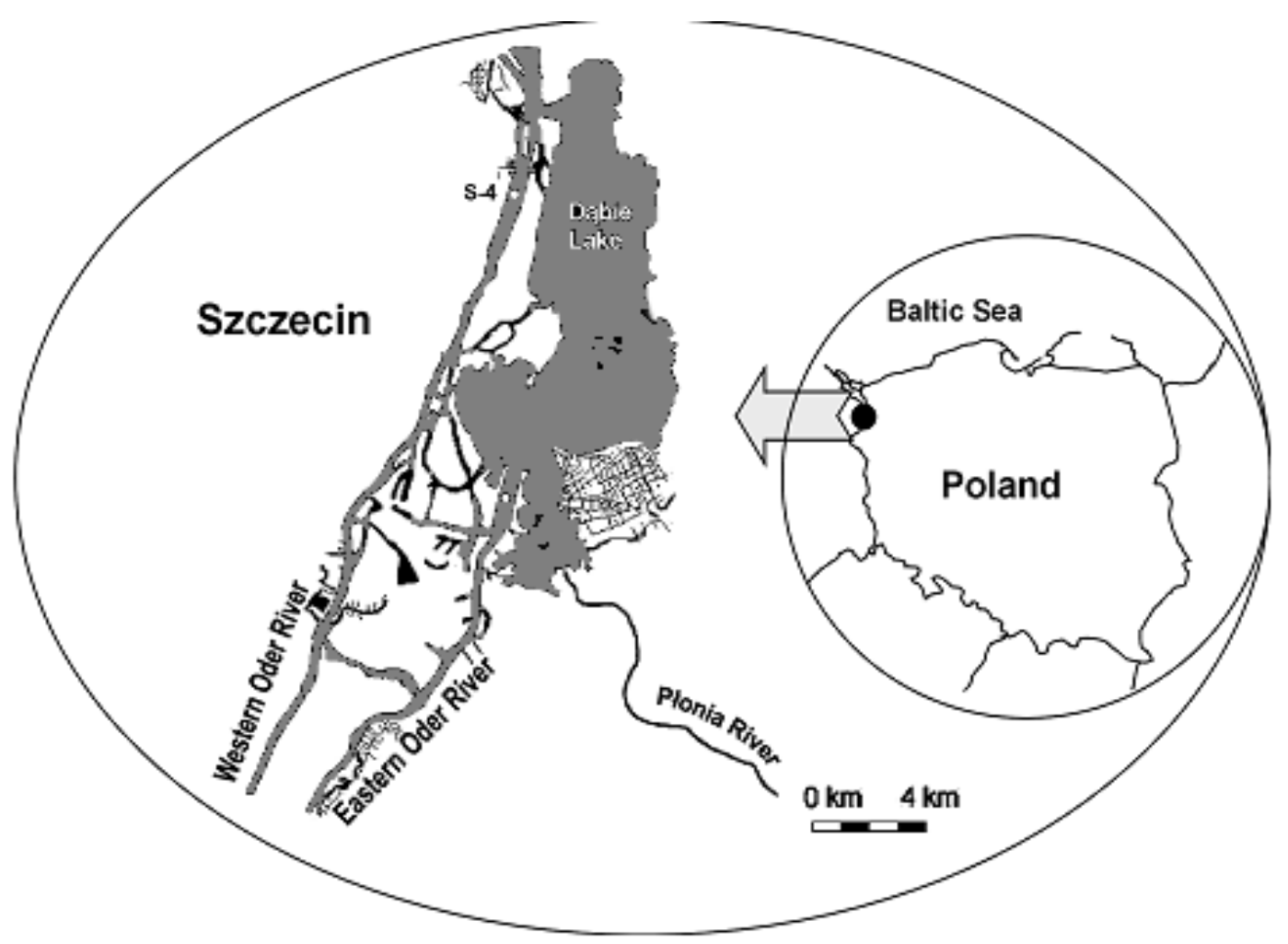

Figure 1. Dąbie Lake.

Research was carried out in the years 2008-2009, in the period from April to October.

The water samples collected from different sampling stations were filtered using $(0.45 \mu \mathrm{m}$ pore size) filter paper to remove suspended particles. Filtrates were preserved in polythene bottles. In order to prevent the precipitation of metals $2 \mathrm{~mL}$ nitric acid was added to the filtrate [60]. 
The samples were concentrated to tenfold on a water bath and subjected to nitric acid digestion $[13,41]$. About $400 \mathrm{~mL}$ of the sample was transformed into clean glass separating funnel in which $10 \mathrm{~mL}$ of $2 \%$ ammonium pyrrolidine dithiocarbamate, $4 \mathrm{~mL}$ of $0.5 \mathrm{M} \mathrm{HCl}$ and $10 \mathrm{~mL}$ of methyl isobutyl ketone (MIBK) are added [47,60]. The solution in separating funnel was shaken vigorously for $2 \mathrm{~min}$ and was left undisturbed for the phases to separate.

The MIBK extract containing the desired metals was then diluted to give final volumes depending on the suspected level of the metals $[12,19,20,60]$. The sample solution was then aspirated into air acetylene flame in an atomic absorption spectrophotometer.

The analysis for the majority of the trace metals like Cadmium (Cd), Chromium (Cr), Copper $(\mathrm{Cu})$, Mercury $(\mathrm{Hg})$, Nickel $(\mathrm{Ni})$, Lead $(\mathrm{Pb})$ and Zinc $(\mathrm{Zn})$ was done by Atomic Absorption Spectrophotometer.

\section{RESULTS AND DISCUSSION}

The experimental data on toxic heavy metals in water samples collected along the in water of the Dąbie Lake from the month of 2008-2009 (April to October) is presented in Table 1 and 2. In the present investigation in water in the Dąbie Lake, it was observed that the maximum concentration of $\mathrm{Cd}$ was $0.82 \mathrm{ppm}$ and the minimum was $0.42 \mathrm{ppm}$. While the annual average concentration was calculated as $0.58 \mathrm{ppm}$ in 2008 of the year, $0.65 \mathrm{ppm}$ in 2009 of the year.

Table 1. Heavy metals content in water samples collected from Dąbie Lake (April to October 2008).

\begin{tabular}{|c|c|c|c|c|c|c|c|}
\hline $\begin{array}{c}\text { Heavy } \\
\text { Metals } \\
\text { (ppm) }\end{array}$ & $\mathbf{C d}$ & $\mathbf{C r}$ & $\mathbf{C u}$ & $\mathbf{H g}$ & $\mathbf{N i}$ & $\mathbf{P b}$ & $\mathbf{Z n}$ \\
\hline $\begin{array}{c}\text { Apr. } \\
\mathbf{2 0 0 8}\end{array}$ & 0.42 & 0.18 & 0.05 & 0.05 & 2.56 & 0.05 & 3.38 \\
\hline $\begin{array}{c}\text { May } \\
\mathbf{2 0 0 8}\end{array}$ & 0.76 & 0.23 & 0.08 & 0.04 & 2.42 & 0.07 & 3,47 \\
\hline $\begin{array}{c}\text { June } \\
\mathbf{2 0 0 8}\end{array}$ & 0.69 & 0.25 & 0.08 & 0.06 & 2.61 & 0.06 & 3.39 \\
\hline $\begin{array}{c}\text { July } \\
\mathbf{2 0 0 8}\end{array}$ & 0.54 & 0.22 & 0.05 & 0.05 & 2.73 & 0.07 & 3.27 \\
\hline $\begin{array}{c}\text { Aug. } \\
\mathbf{2 0 0 8}\end{array}$ & 0.71 & 0.18 & 0.06 & 0.04 & 2,89 & 0.05 & 3.45 \\
\hline $\begin{array}{c}\text { Sept. } \\
\mathbf{2 0 0 8}\end{array}$ & 0.42 & 0.24 & 0.07 & 0.06 & 2.29 & 0.04 & 3.39 \\
\hline $\begin{array}{c}\text { Oct. } \\
\mathbf{2 0 0 8}\end{array}$ & 0.58 & 0.18 & 0.07 & 0.05 & 2.47 & 0.06 & 3.56 \\
\hline Average & 0.59 & 0.21 & 0.06 & 0.05 & 2.57 & 0.06 & 3.41 \\
\hline
\end{tabular}


Table 2. Heavy metals content in water samples collected from Dąbie Lake (April to October 2009).

\begin{tabular}{|c|c|c|c|c|c|c|c|}
\hline $\begin{array}{c}\text { Heavy } \\
\text { Metals } \\
\text { (ppm) }\end{array}$ & Cd & $\mathbf{C r}$ & $\mathbf{C u}$ & $\mathbf{H g}$ & $\mathbf{N i}$ & $\mathbf{P b}$ & $\mathbf{Z n}$ \\
\hline $\begin{array}{c}\text { Apr. } \\
\mathbf{2 0 0 8}\end{array}$ & 0.69 & 0.19 & 0.05 & 0.04 & 2.83 & 0.05 & 2.85 \\
\hline $\begin{array}{c}\text { May } \\
\mathbf{2 0 0 8}\end{array}$ & 0.43 & 0.21 & 0.08 & 0.05 & 2.69 & 0.05 & 3,59 \\
\hline $\begin{array}{c}\text { June } \\
\mathbf{2 0 0 8}\end{array}$ & 0.71 & 0.23 & 0.07 & 0.03 & 2.86 & 0.04 & 3.53 \\
\hline $\begin{array}{c}\text { July } \\
\mathbf{2 0 0 8}\end{array}$ & 0.66 & 0.28 & 0.06 & 0.05 & 2.59 & 0.07 & 3.65 \\
\hline $\begin{array}{c}\text { Aug. } \\
\mathbf{2 0 0 8}\end{array}$ & 0.59 & 0.21 & 0.05 & 0.05 & 2,75 & 0.06 & 3.83 \\
\hline $\begin{array}{l}\text { Sept. } \\
\mathbf{2 0 0 8}\end{array}$ & 0.82 & 0.12 & 0.06 & 0.03 & 2.53 & 0.05 & 3.71 \\
\hline $\begin{array}{c}\text { Oct. } \\
\mathbf{2 0 0 8}\end{array}$ & 0.69 & 0.23 & 0.05 & 0.06 & 2.79 & 0.07 & 3.47 \\
\hline Average & 0.65 & 0.21 & 0.06 & 0.04 & 2.72 & 0.05 & 3.52 \\
\hline
\end{tabular}

The values obtained were found to be below the permissible limit of $2.0 \mathrm{ppm}$ set for inland surface water [60]. There are a few recorded instances Cadmium poisoning in human beings following consumption of contaminated fishes $[19,20,60]$. Cadmium it is less toxic to plants than $\mathrm{Cu}$, similar in toxicity to $\mathrm{Pb}$ and $\mathrm{Cr}[19,20,60]$. It is equally toxic to invertebrates and fishes $[19,20,40,60]$. In aquatic systems, cadmium is most readily absorbed by organisms directly from the water in its free ionic form Cd (II) $[5,19,20,60]$.

The acute toxicity of cadmium to aquatic organisms is variable, even between closely related species, and is related to the free ionic concentration of the metal $[5,19,20,60]$. Cadmium interacts with the calcium metabolism of animals $[5,19,20,60]$. In fish it causes lack of calcium (hypocalcaemia), probably by inhibiting calcium uptake from the water $[5,19,20,60]$.

In the present investigation in water in the Dąbie Lake, it was observed that the maximum concentration of $\mathrm{Cr}$ was $0.28 \mathrm{ppm}$ and the minimum was $0.12 \mathrm{ppm}$. While the annual average concentration was calculated as $0,21 \mathrm{ppm}$ in 2008 of the year, $0.21 \mathrm{ppm}$ in 2009 of the year.

Which was very much above the permissible limit of $0.1 \mathrm{ppm}$ set for inland surface water [60]. For invertebrates and fishes, its toxicity is not much acute [60]. Chromium is generally more toxic at higher temperatures and its compounds are known to cause cancer in humans $[19,20,60]$. The toxic effect of Chromium on plants indicate that the roots remain small and the leaves narrow, exhibit reddish brown discoloration with small necrotic blotches [29]. Symptoms of Chromium phytotoxicity include inhibition of seed germination or of early seedling development, reduction of root growth, leaf chlorosis and depressed biomass $[19,20,50,60]$.

From the results it appears that the $\mathrm{Cu}$ content in water in the Dąbie Lake, was minimum of $0.05 \mathrm{ppm}$ and maximum of $0.07 \mathrm{ppm}$. The observed annual average concentration of Copper in the water was $0.06 \mathrm{ppm}$ in 2008 of the year, $0.06 \mathrm{ppm}$ in 2009 of the year. Which was below the permissible limit of $3.0 \mathrm{ppm}$ set for inland surface water [60]. 
It is important here to note that Copper is highly toxic to most fishes, invertebrates and aquatic plants than any other heavy metal except mercury [60]. It reduces growth and rate of reproduction in plants and animals [60]. The chronic level of $\mathrm{Cu}$ is $0.02-0.2 \mathrm{ppm}[60,66]$. Aquatic plants absorb three times more Copper than plants on dry lands [60]. Excessive Copper content can cause damage to roots, by attacking the cell membrane and destroying the normal membrane structure, inhibited root growth and formation of numerous short, brownish secondary roots $[60,66]$. Copper is highly toxic in aquatic environments and has effects in fish, invertebrates, and amphibians, with all three groups equally sensitive to chronic toxicity $[19,20,27,60]$. Copper also causes reduced sperm and egg production in many species of fish $[19,20,52-55,60,65]$.

In the present investigation in water in the Dąbie Lake, it was observed that the maximum concentration of $\mathrm{Hg}$ was $0.06 \mathrm{ppm}$ and the minimum was $0.03 \mathrm{ppm}$. While the annual average concentration was calculated as $0.05 \mathrm{ppm}$ in 2008 of the year, $0.04 \mathrm{ppm}$ in 2009 of the year. Which was very much above the maximum limit of $0.01 \mathrm{ppm}$ set for inland surface water [60]. Mercury is generated naturally in the environment from the degassing of the earth's crust from volcanic emissions [60].

The organic form is readily absorbed in the gastrointestinal tract (90-100\%), lesser but still significant amounts of inorganic mercury are absorbed in the gastrointestinal tract (7-15 \%) [60]. Previous study have reported that Mercury in dissolved form enter the fish through the gills $[14,19,20,60]$. Further studies have indicated that inorganic Mercury get adsorbed to the suspended particulate matter and settles down [32,19,20,60]. Further gets methylated and ultimately enter the food chain, resulting in bioaccumulation [60].

The monthly concentration of $\mathrm{Ni}$ in the water in Dąbie Lake samples was found to be in the range of $2.29 \mathrm{ppm}-2.89 \mathrm{ppm}$. The annual average concentration of Nickel in the water samples was observed to be $2.57 \mathrm{ppm}$ in 2008 of the year, $2.72 \mathrm{ppm}$ in 2009 of the year.

Which is close to the limit of $3.0 \mathrm{ppm}$ set for inland surface water [60]. Short-term exposure to Nickel on human being is not known to cause any health problems, but long-term exposure can cause decreased body weight, heart, liver damage and skin irritation $[19,20,60,66]$.

In the present investigation in water in the Dąbie Lake, it was observed that the maximum concentration of $\mathrm{Pb}$ was $0.07 \mathrm{ppm}$ and the minimum was $0.04 \mathrm{ppm}$. The annual average concentration of $\mathrm{Pb}$ in the water samples was observed to be $0.06 \mathrm{ppm}$ in 2008 of the year, $0.05 \mathrm{ppm}$ in 2009 of the year. Which is above the permissible limit of $0.1 \mathrm{ppm}$ set for inland surface water [60]. Acute toxicity generally appears in aquatic plants at concentration of $0.1-5.0 \mathrm{ppm}[60,66]$. In plants, it initially results in enhanced growth, but from a concentration of $5 \mathrm{ppm}$ onwards, this is counteracted by severe growth retardation, discoloration and morphological abnormalities [60]. There is an adverse influence on photosynthesis, respiration and other metabolic processes [60]. Acute toxicity of Lead in invertebrates is reported at concentration of $0.1-10 \mathrm{ppm}[19,20,60,66]$ Higher levels pose eventual threat to fisheries resources [60]. A number of studies have investigated effects of prolonged Lead exposure on freshwater fish [60]. These studies report a wide range of effects induced by chronic exposure to elevated Lead concentrations, oocyte growth, including effects on pituitary function, gonadosomatic index [19,20,46,60].

In the present study in water in the Dąbie Lake, the monthly concentration of Zinc was in the range of $2.85 \mathrm{ppm}$ to $3.83 \mathrm{ppm}$. The results of the present investigation indicate that the annual average concentration of $\mathrm{Zn}$ in water samples was $3.41 \mathrm{ppm}$ in 2008 of the year, $3.52 \mathrm{ppm}$ in 2009 of the year. Which is above the permissible limit of $5.0 \mathrm{ppm}$ set for inland surface water [60]. Zn may result in ne crosis, chlorosis and inhibited growth of plants $[60,66]$. Previous studies have reported toxic effect of Zinc on some aquatic organisms such as fish $[3,19,20,60]$. Although there is low toxicity effect of $\mathrm{Zn}$ in man, however, the 
prolonged consumption of large doses has been reported to show some health complications such as fatigue, dizziness and neutropenia $[19,20,27,60]$.

\section{CONCLUSION}

The pollution of the aquatic environment with heavy metals has become a worldwide problem during recent years, because they are indestructible and most of them have toxic effects on organisms.

Heavy metals in water refers to the heavy, dense, metallic elements that occur in trace levels, but are very toxic and tend to accumulate, hence are commonly referred to as trace metals. The major anthropogenic sources of heavy metals are industrial wastes from mining sites, manufacturing and metal finishing plants, domestic waste water and run off from roads.

In the present investigation in water in the Dąbie Lake, it was observed that the:

- maximum concentration of $\mathrm{Cd}$ was $0.82 \mathrm{ppm}$ and the minimum was $0.42 \mathrm{ppm}$ (the values obtained were found to be below the permissible limit of $2.0 \mathrm{ppm}$ set for inland surface water),

- maximum concentration of $\mathrm{Cr}$ was $0.28 \mathrm{ppm}$ and the minimum was $0.12 \mathrm{ppm}$ (which was very much above the permissible limit of $0.1 \mathrm{ppm}$ set for inland surface water),

- minimum concentration of $\mathrm{Cu}$ was $0.05 \mathrm{ppm}$ and maximum of $0.07 \mathrm{ppm}$ (which was below the permissible limit of $3.0 \mathrm{ppm}$ set for inland surface water),

- maximum concentration of $\mathrm{Hg}$ was $0.06 \mathrm{ppm}$ and the minimum was $0.03 \mathrm{ppm}$ (which was very much above the maximum limit of $0.01 \mathrm{ppm}$ set for inland surface water),

- minimum concentration of Ni was $2.29 \mathrm{ppm}$ and maximum of $2.89 \mathrm{ppm}$ (which is close to the limit of $3.0 \mathrm{ppm}$ set for inland surface water),

- maximum concentration of $\mathrm{Pb}$ was $0.07 \mathrm{ppm}$ and the minimum was $0.04 \mathrm{ppm}$ (which is above the permissible limit of $0.1 \mathrm{ppm}$ set for inland surface water),

- minimum concentration of $\mathrm{Zn}$ was $2.85 \mathrm{ppm}$ and maximum $3.83 \mathrm{ppm}$ (which is above the permissible limit of $5.0 \mathrm{ppm}$ set for inland surface water).

\section{References}

[1] Adams W. J., Kimerle R. A., Barnett J. W. Jr., Environ. Sci. Technol. 26(10) (1992) 1864-1875.

[2] Aghor A., Chemicals make Thane creek the worst polluted waterbody, Daily DNA, August 4, 2007. Mumbai, India, 2007

[3] Alabaster J. S., Lloyds R., Water quality criteria for freshwater fish. Second edition, Butterworths publication, London 1982, pp. 361.

[4] Ali N. A., Ater M., Sunahara G. L., Robidoux P. Y., Ecotoxicology and Environmental Safety 57(3) (2004) 363-374.

[5] AMAP. Assessment report: Arctic pollution issues. Arctic Monitoring and Assessment Programme, Oslo 1998.

[6] Baršytè Lovejoy D., Acta Zoologica Lituanica. Hydrobiologia 9(2) (1999) 12-20.

[7] Baldwin D. H., Sandahl J. F., Labenia J. S., Scholz N. L., Environmental Toxicology and Chemistry 22(10) (2003) 2266-2274. 
[8] Bradl H., Heavy Metals in the Environment: Origin, Interaction and Remediation, Elsevier/Academic Press, London 2005.

[9] Cai L., Liu G., Rensing C., Wang G., BMC Microbiology 9(4) (2009), doi:10.1186/1471 2180-9-4.

[10]Carlos-Tarres-Guzman M., Moreno-Sanchez R., FEMS Microbiol. Rev. 25(3) (2001) 335-347.

[11]Cervantes C., Campos-Garcia J., Debars S., Gutierrez-Corona F., Loza-Tavera H., Chatterjee J., Chatterjee C., Environ. Pollut. 109(1) (2000) 69-74.

[12]Chen M., Ma L. Q., Soil Science Society of American Journal 65(2) (2001) 491-499.

[13]Clesceri L. S., Standard methods for the examination of Water and waste water. In Arnold, E., Greenbergy, Eaton, A.D. (Eds.): Collection and Preservation of Samples And Metals, pp.1-27, pp.1-35, pp.3-1, pp.3-21, APHA, AWWA, WEF, Washington DC 1998.

[14]Dalman O., Demirak A., Balci A., Food Chem. 95 (2006) 157-162.

[15]Daniszewski P., International Letters of Chemistry, Physics and Astronomy 3 (2012) 8692.

[16]Daniszewski P., International Letters of Chemistry, Physics and Astronomy 4 (2012) $112-$ 118.

[17]Daniszewski P., International Letters of Chemistry, Physics and Astronomy 5 (2012) 8087

[18]Daniszewski P., Konieczny R., International Letters of Chemistry, Physics and Astronomy 4 (2013) 91-97.

[19]Daniszewski P., Konieczny R., International Letters of Chemistry, Physics and Astronomy 8(3) (2013) 269-278.

[20]Daniszewski P., Konieczny R., International Letters of Chemistry, Physics and Astronomy 8(3) (2013) 279-287.

[21]Das H. K., Mitra A. K., Sengupta P. K., Hossain A., Islam F., Rabbani, G. H., Environment International. 30(3) (2004) 383-387.

[22]Dube B. K., Tewari K., Chatterjee J., Chaterejee C., Chemosphere 53(9) (2003) 11471153.

[23]Ezeonyejiaku C. D., Obiakor, M. O., Ezenwelu C. O., Online Journal of Animal and Feed Research 1(4) (2011) 130-134.

[24]Forstner U., Wittmann G. T. W., Metal Pollution in the Aquatic Environment. SpringerVerlag, Berlin 1979.

[25]Gbaruko B. C., Ana G. R. E. E., Nwachukwu J. K., African Journal of Biotechnology $7(25)(2008)$ 4737-4742.

[26] Health Organisation, International Programme on Chemical Safety (IPCS), Geneva 1992, Switzerland.

[27]Hess R., Schmid B., J. Paediatr. Haematol./Oncol. 24 (2002) 582-584.

[28]Horne M. T., Dunson W. A., Archives of Environmental Contamination and Toxicology 29(4) (1995) 500-505. 
[29]Jha S. K., Chavan S. B., Pandit G. G., Negi B. S., Sadasivan S., Environmental Monitoring and Assessment 76(2) (2002) 249-262.

[30]Kabata-Pendias A., Pendias H., Trace Elements in Soils and Plants. 2nd ed. CRC Press, Boca Raton 1992, pp.365.

[31]Kazi T. G., Arain M. B., Baig J. A., The Science of the Total Environment 407(3) (2009) 1019-1026.

[32]Kehrig H.A., Malm O., Moreira I., Sci. Tot. Environ. 213(1-3) (1998) 263-271.

[33]Khunyakari R. P., Vrushali T., Sharma R. N., Tare V., Journal of Environmental Biology 22 (2) (2001) 141-144.

[34]Lokhande R. S., Kelkar N., Indian Journal of Environmental Protection 19(9) (1999) 664-668.

[35]Lokhande R. S., Singare P. U., Pimple D. S., Resources and Environment. 1(1) (2011) 13-19.

[36]Lokhande R. S., Singare P. U., Pimple D. S., World Environment 1(1) (2011) 6-13.

[37]Maher W., Batley G. E., Lawrence I., Freshwater Biol. 41(2) (1999) 361-372.

[38]Menounou N., Presley B. J., Arch. Environ. Contam. Toxicol. 45(1) (2003) 11-29.

[39]Momot O., Synzynys B., Int. J. Environ. Res. Public Health 2 (2005) 214-218.

[40]Moore J. W., Ramamoorthy S., Heavy Metals in Natural Waters: Applied Monitoring and Impact Assessment, Springer-Verlag, New York 1984, pp. 28-246.

[41]Neff J. M., Environmental Toxicology and Chemistry 16(5) (1997) 917-927.

[42]Ong M., Kamaruzzaman B., Amer. J. App. Sci. 6 (2009) 1418-1423.

[43]Paar A., Microwave Sample Preparation System - Instruction Handbook, Anton Paar $\mathrm{GmbH}$, Austria 1998, pp. 128.

[44]Patil D., A lot's fishy about our creek and lake fish. Daily Times of India. March 22, Mumbai 2009, India. Obtained through the Internet.

[45]Pyatt A. J., Pyatt F. B., Pentreath V. W., Invertebr Neurosci. 4(3) (2002) 135-140.

[46]Rai U. N., Tripathi R. D., Kumar N., Chromosphere. 25 (1992) 721-732.

[47]Rozsa K. S., Salanki J., Cell Mol. Neurobiol. 14(6) (1994) 735-754.

[48]Ruby S. M., Hull R., Anderson P., Arch Environ Contam Toxicol. 38(1) (2000) 46-51.

[49]Sachdev S. L., West P. W., Environmental Science \& Technology 4(9) (1970) 749-751.

[50] Saxena D. K., Srivastava K., Singh S., Current Science 94(7) (2008) 901-904.

[51] Sharma D. C., Pant R. C., Journal of Environmental Science and Health. Part A 29(5) (1994) 941-948.

[52] Sharma R. K., Agrawal M., Marshall F. M., Effects of waste water irrigation on heavy metal accumulation in soil and plants, Paper presented at the National Seminar, Bangalore University, Bangalore 2004, India.

[53] Singare P. U., Interdisciplinary Environmental Review 12(4) (2011) 298-312.

[54]Singare P. U., Lokhande R. S., Bhanage S. V., International Journal of Global Environmental Issues. 11(1) (2011) 79-90. 
[55]Singare P. U., Lokhande R. S., Naik K. U., Interdisciplinary Environmental Review 12(3) (2011) 215-230.

[56] Singare P. U., Lokhande R. S., Naik K. U., Interdisciplinary Environmental Review 11(1) (2010) 90-107.

[57] Singare P. U., Mishra R. M., Trivedi M. P., Advances in Analytical Chemistry 2(3) (2012) 14-24.

[58] Singare P. U., Mishra R. M., Trivedi M. P., Frontiers in Science. 2(3) (2012) 28-36.

[59] Singare P. U., Thane lakes high on metal content: Study, Daily Times of India, August 10, 2011. Mumbai, India.

[60] Singare P. U., Trivedi M. P., Mishra R. M., American Journal of Chemistry 2(3) (2012) 171-180.

[61] Singare P. U., Trivedi M. P., Mishra R. M., Science and Technology 2(4) (2012) 87-97.

[62] Singare P. U., Talpade M. S., Dagli D. S., Bhawe V. G., International Letters of Chemistry, Physics and Astronomy 8(2) (2013) 94-104

[63] Spooner D. R., Maher W., Otway N., Arch. Environ. Contam. Toxicol. 45(1) (2013) 92101.

[64] Surujdeo-Maharaj S. A., In prep. Heavy metals in water, sediment and biota of rivers in Trinidad and Tobago. Ph.D. Thesis, The University of the West Indies, St Augustine, Trinidad.

[65] Swamy Y. V., Roy Chaudhury G., Das S. N., Sengupta S., Muduli R., Current Science 91(10) (2006) 1409-1412.

[66]Szucs A., Salanki J., Rozsa K. S., Cell Mol. Neurobiol. 14(6) (1994) 769-780.

[67]Taub Frieda B., Fish 430 lectures (Biological Impacts of Pollutants on Aquatic Organisms), University of Washington College of Ocean and Fishery Sciences, Seattle 2004, WA.

[68] Tiwana N. S., Jerath N., Singh G., Ravleen (Eds.), Heavy metal pollution in Punja Rivers, in Newsletter Environmental Information System (ENVIS), Punjab State Council for Science and Technology, India, 3(1) (2005) 3.

[69] Vymazal J., Algae and Element Cycling in Wetlands. Lewis Pub., Boca Raton 1995, pp. 689.

[70]WHO. Cadmium - environmental aspects. Environmental Health Criteria 135. World

[71]Wright D. A., Welbourn P., Environmental Toxicology, Cambridge University Press, Cambridge 2002, U.K.

[72]Jańczak J., Atlas Polish Lakes 1996, 98-99.

[73]Protasowicki M., Acta Ichthyol. et Piscat. 21 (1991) 301-309.

[74]Protasowicki M., Niedźwiecki E., Ciereszko W., Heavy metals and chloroorganic substances in sediment cores from the Szczecin Lagoon. In: Pollutants in Environment, (eds.A. Smoczyńska et al.), ART Olsztyn, 1993, 155-159.

[75]Protasowicki M., Niedźwiecki E., Ciereszko W., Perkowska A., Meller E., Acta Hydrochim. Hydrobiol. 27(5) (1990) 338-342. 
[76]Borówka R. K., 2002, Środowisko geograficzne, Budowa geologiczna i rozwój krajobrazu, [In:] Przyroda Pomorza Zachodniego (ed.: M. Kaczanowska), Wyd. Oficyna In Plus, Szczecin, 40-56.

[77]Borówka R. K., Witkowski A., Tomkowiak J., Olas M., Gusar K., Liszkiewicz E., 1999, Stratygraficzna $i$ przestrzenna zmienność litologiczna $i$ geochemiczna osadów wypetniajacych Zalew Szczeciński $i$ baseny przyległe, In: Ewolucja geosystemow nadmorskich Południowego Bałtyku (eds.: R. K. Borowka, Z. Młynarczyk, A. Wojciechowski), Bogucki Wydawnictwo Naukowe, Poznań - Szczecin.

[78] Wiśniewski B., 1999, Współczesne zmiany średniego poziomu morza w Świnoujściu, In: Ewolucja geosystemów nadmorskich Poludniowego Bałtyku, (eds.: R. K. Borówka, Z. Młynarczyk, A. Wojciechowski), Bogucki Wydawnictwo Naukowe, Poznań - Szczecin. 